\title{
Concentration, Size Distribution, and Formation of Trimethylaminium and Dimethylaminium Ions in Atmospheric Particles over Marginal Seas of China*
}

\author{
Qinguing Hu, Peiran Yu, Yujiao Zhu, Kai Li, and Huiwang Gao \\ Key Laboratory of Marine Environmental Science and Ecology, Ocean University of China, Ministry of Education, Qingdao, China \\ XIAOHONG YAO \\ Key Laboratory of Marine Environmental Science and Ecology, Ocean University of China, Ministry of Education, and Qingdao \\ Collaborative Innovation Center of Marine Science and Technology, Qingdao, China
}

(Manuscript received 30 December 2014, in final form 28 April 2015)

\begin{abstract}
In this paper, the concentration, the size distribution, and the formation of dimethylaminium $\left(\mathrm{DMA}^{+}\right)$and trimethylaminium $\left(\mathrm{TMA}^{+}\right.$) ions in atmospheric particles were studied during a cruise campaign over the Yellow Sea and the Bohai Sea of China in May 2012. The concentrations of $\mathrm{DMA}^{+}$and $\mathrm{TMA}^{+}$in particles smaller than $11 \mu \mathrm{m}$ were $4.4 \pm 3.7$ and $7.2 \pm 7.1 \mathrm{nmol} \mathrm{m}^{-3}$, respectively. The two ions had a good correlation $\left(R^{2}=0.86\right)$, and both had a moderately good correlation with chlorophyll a fluorescence $\left(R^{2}=0.66-0.67\right)$. The observed concentrations were from one to three orders of magnitude larger than the concentrations reported in other marine atmospheres. They were also much larger than the values observed at a coastal site neighboring the Yellow Sea in May-June 2013. The high concentrations of $\mathrm{DMA}^{+}$and $\mathrm{TMA}^{+}$observed in the marine atmosphere were probably associated with local biogenic activity instead of the long-range transport of these species from adjacent continents. The calculated mole ratios of $\left(\mathrm{DMA}^{+}+\mathrm{TMA}^{+}\right)$to $\mathrm{NH}_{4}^{+}$ in different-sized particles over the seas indicated that $\left(\mathrm{DMA}^{+}+\mathrm{TMA}^{+}\right)$most likely played an important role in neutralizing acidic species in particles less than $0.43 \mu \mathrm{m}$ but not in particles of other sizes. Size distributions of $\mathrm{DMA}^{+}$and $\mathrm{TMA}^{+}$in the marine and coastal atmospheres were analyzed in terms of the respective contribution of gas-particle partitioning, cloud/fog processing of $\mathrm{TMA}^{+}$and $\mathrm{DMA}^{+}$, bioaerosols, and sea-salt aerosols to the observed concentrations of the two ions over the seas.
\end{abstract}

\section{Introduction}

In the atmosphere, amines are alkaline organic gases that can react with acid $\left(\mathrm{HNO}_{3}\right.$ or $\left.\mathrm{H}_{2} \mathrm{SO}_{4}\right)$ to form aminium salts or experience photooxidation to form secondary organic aerosols (Ge et al. 2011b). Aminium salts have been determined to play an important role in

\footnotetext{
* Supplemental information related to this paper is available at the Journals Online website: http://dx.doi.org/10.1175/JAS-D-140393.s1.

Corresponding author address: Xiaohong Yao, Key Laboratory of Marine Environmental Science and Ecology, College of Environmental Science and Engineering, Ocean University of China, Ministry of Education, No. 238, Songling Road, Laoshan District, Qingdao 266100, China.

E-mail:xhyao@ouc.edu.cn
}

enhancing the formation and growth of new particles in the atmosphere (Kulmala et al. 2013; Smith et al. 2010). Dimethylamine (DMA) and trimethylamine (TMA) are two of the most common alkaline organic gases and account for the largest quantities of aliphatic amines in the atmosphere (Schade and Crutzen 1995; Ge et al. 2011a). In the continental atmosphere, the major sources of DMA and TMA are similar to the major sources of ammonia, including animal husbandry, soil, and vehicle emissions (Ge et al. 2011a). Oceans are also an important emission source for amines, and they release approximately $0.8 \mathrm{Tg}$ of amines to the atmosphere per year (Ge et al. 2011a; Myriokefalitakis et al. 2010). In marine environments, DMA and TMA can both be produced by bacterial degradation of glycine and choline (especially choline) in seawater (Carpenter et al. 2012; Welsh 2000). Concentrations of DMA and TMA 
in seawater vary in different oceans and in various marine atmospheres (Gibb et al. 1999a,b; Van Neste et al. 1987). For example, $\mathrm{TMA}^{+}$concentrations are larger than $\mathrm{DMA}^{+}$concentrations in the coastal waters around Hawaii (Van Neste et al. 1987). However, concentrations of DMA or $\mathrm{DMA}^{+}$exceeded the concentrations of TMA or $\mathrm{TMA}^{+}$in the atmosphere over the Arabian Sea, regardless of whether they were present in the gas or particle phases (Gibb et al. 1999a).

In marine atmospheric aerosols, high concentrations of $\mathrm{DMA}^{+}$and $\mathrm{TMA}^{+}$are sometimes associated with high biological activity, such as an algal bloom (Facchini et al. 2008a,b; Müller et al. 2009). $\mathrm{DMA}^{+}$and $\mathrm{TMA}^{+}$in particulate form could originate from sea spray (Gorzelska and Galloway 1990), bursting of bubbles (Milne and Zika 1993), or gas-to-particulate conversion (Facchini et al. 2008a,b; Ge et al. 2011a; Sorooshian et al. 2009; Healy et al. 2015). However, Facchini et al. (2008a) reported that the concentrations of $\mathrm{DMA}^{+}$and diethylamine ${ }^{+}\left(\mathrm{DEA}^{+}\right)$in seawater bubble-bursting aerosols were always below the detection limit, indicating that the pathway was a negligible source of these ions in marine atmospheres. Gaston et al. (2013) recently reported that $\mathrm{TMA}^{+}$detected in particles in the marine environment off the coast of California was of secondary origin, associated with animal husbandry activities inland, rather than local marine biogenic emissions. Considering that concentrations of $\mathrm{DMA}^{+}$and $\mathrm{TMA}^{+}$ were highly variable in different oceans, more studies for $\mathrm{DMA}^{+}$and $\mathrm{TMA}^{+}$in marine atmospheric aerosols are needed for better understanding of their concentrations, origins, and formation pathways.

The Yellow Sea and the Bohai Sea are two marginal seas of China. The Bohai Sea suffers from severe eutrophication, and high concentrations of chlorophyll a occur from spring through fall (Tan et al. 2011). Approximately one-third of the Yellow Sea also suffers from severe eutrophication, and abundant nutrients sometimes cause algal blooms during spring (Yamaguchi et al. 2013). High emissions of amines are expected when algal blooms occur in nutrient-enriched areas of the two seas. However, amine emissions can be very low in those oligotrophic areas of the Yellow Sea. Thus, the two marginal seas provide an ideal place to investigate $\mathrm{DMA}^{+}$and $\mathrm{TMA}^{+}$in marine atmospheric aerosols with highly varying concentrations of chlorophyll a.

In this study, we took part in a Chinese oceanographic survey project in May 2012. In that period, the nutrients accumulated in the winter were almost completely depleted in the oligotrophic areas of the Yellow Sea. However, strong biogenic activity existed in nutrientenriched areas of the two seas. The objectives of this work include the following: 1) to study spatial and temporal variations of particulate $\mathrm{DMA}^{+}$and $\mathrm{TMA}^{+}$in mole concentrations over the Yellow Sea and the Bohai Sea relative to biogenic activity; 2) to investigate the size distribution and the formation of $\mathrm{DMA}^{+}$and $\mathrm{TMA}^{+}$in particles of different sizes; and 3) to investigate the role of $\mathrm{DMA}^{+}$and $\mathrm{TMA}^{+}$in neutralizing acidic species in particles of different sizes. However, we found that the size spectra of $\mathrm{DMA}^{+}$and $\mathrm{TMA}^{+}$in the marine atmosphere were complicated and difficult to resolve. Thus, we measured concentrations of $\mathrm{DMA}^{+}$and $\mathrm{TMA}^{+}$in particles of different sizes at a coastal site neighboring the Yellow Sea in May-June 2013. The coastal size distribution data were analyzed in terms of the module structure of the size distribution of $\mathrm{DMA}^{+}$and $\mathrm{TMA}^{+}$in mass concentration and the sources and atmospheric processes with which they were associated. Using the coastal data as a reference, we chose various multiple lognormal functions fitting the complicated size spectra in the marine atmosphere, and we thereby identified formation pathways and primary sources for the two ions.

\section{Experiment}

We participated in a cruise campaign over the Yellow Sea and the Bohai Sea during 2-21 May 2012 (Fig. 1a), when a high-concentration gradient of chlorophyll a occurred over different sea areas. From 2 to 9 May 2012, the research vessel (R/V) Dong Fang Hong II cruised in the Yellow Sea. From the night of 19 May to 20 May, the vessel cruised in the Bohai Sea. A low-volume Anderson cascade impactor (AN-200; Sibata Co., Inc., Japan) was employed to collect size-segregated atmospheric particles with a flow rate of $28.3 \mathrm{~L} \mathrm{~min}^{-1}$. The $50 \%$ aerodynamic cutoff diameters were 11, 7.0, 4.7, 3.3, 2.1, 1.1, 0.65 , and $0.43 \mu \mathrm{m}$, respectively. All samples were collected on 80-mm fiber-film filters (Pallflex T60A20; Pall Co., Inc., United States). The sampling duration was 6-12 h, except for a sample collected from the night of 5 May through the daytime of 6 May ( $22 \mathrm{~h})$. The sampler was deployed on the upper deck of the vessel and was about $8 \mathrm{~m}$ above the sea surface. To avoid selfcontamination from the ship exhaust, the sampling was conducted only when the ship was sailing, and the wind direction ranged from $-90^{\circ}$ to $90^{\circ}$ relative to the bow of the ship. The collected samples were wrapped in baked aluminum foil and sealed in polyethylene bags with silica gel, then stored at $-20^{\circ} \mathrm{C}$ before chemical analysis. A total of 16 samples and one field blank were collected.

During 20 May-2 June 2013, a 14-stage nano-MicroOrifice Uniform Deposition Impactors (MOUDI) sampler was used for sampling at a coastal site. The sampling site was located at the campus of the Ocean University of China $\left(36.1^{\circ} \mathrm{N}, 120.5^{\circ} \mathrm{E}\right)$, about $15 \mathrm{~m}$ above ground level and about $7 \mathrm{~km}$ from the Yellow Sea. The 

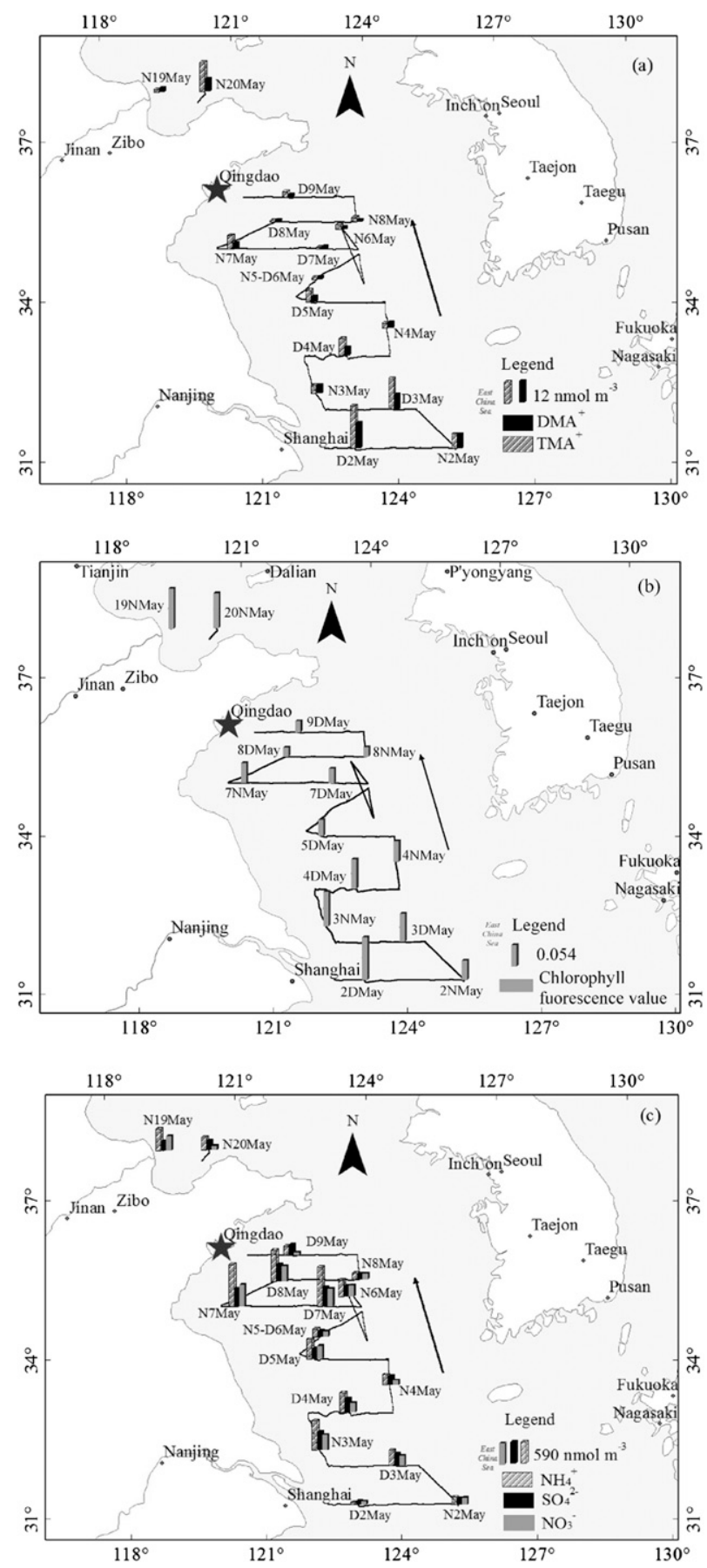

FIG. 1. Temporal and spatial variations of concentrations of (a) $\mathrm{DMA}^{+}$and $\mathrm{TMA}^{+}$in $\mathrm{PM}_{11}$; (b) chlorophyll fluorescence; and (c) concentrations of $\mathrm{NH}_{4}^{+}, \mathrm{SO}_{4}^{2-}$, and $\mathrm{NO}_{3}^{-}$in $\mathrm{PM}_{11}$ during the cruise. In (a), $12 \mathrm{nmol} \mathrm{m}^{-3}$ corresponds to the two heights of the bars. In (c), $590 \mathrm{nmol} \mathrm{m}^{-3}$ corresponds to the three heights of the bars. The letters before the date represent whether the sample was collected in the daytime (D) or in the nighttime (N). sampler operated at a flow rate of $30 \mathrm{~L} \mathrm{~min}^{-1}$, with $50 \%$ cutoff points for particle aerodynamic diameters at 18 , $10,5.6,3.2,1.8,1,0.56,0.32,0.18,0.10,0.056,0.032$, and $0.01 \mu \mathrm{m}$. Teflon filters ( $47 \mathrm{~mm}$; Pall Life Sciences) were used to collect particles larger than $0.1 \mu \mathrm{m}$ and Zefluor filters ( $90 \mathrm{~mm}$; Pall Life Sciences) were used to collect particles smaller than $0.1 \mu \mathrm{m}$. For each day, filters were usually replaced at around 0800 and 2200 local time.

All samples were ultrasonically extracted in deionized water $(18.2 \mathrm{M} \Omega \cdot \mathrm{cm})$ for $20 \mathrm{~min}$ at $0^{\circ} \mathrm{C}$. The extract was filtered through a prebaked Whatman GF/F glass fiber filter. A Dionex Dx-80 ion chromatograph, equipped with different analytical columns, was used to determine $\mathrm{DMA}^{+}, \mathrm{TMA}^{+}, \mathrm{TEA}^{+}, \mathrm{NH}_{4}^{+}, \mathrm{NO}_{3}^{-}, \mathrm{SO}_{4}^{2-}, \mathrm{Cl}^{-}$, and $\mathrm{C}_{2} \mathrm{O}_{4}^{2-}$ (VandenBoer et al. 2011; Yao et al. 2003). Different analytical columns require different leachates for ion analysis [i.e., CS17A using methylsulfonic acid $\left(6 \mathrm{mmol} \cdot \mathrm{L}^{-1}\right)$ to determine amines, CS12A using methylsulfonic acid $\left(18 \mathrm{mmol} \cdot \mathrm{L}^{-1}\right)$ to determine $\mathrm{NH}_{4}^{+}$, and AS11 using $\mathrm{NaOH}\left(3-40 \mathrm{mmol} \mathrm{L}^{-1}\right.$, gradient) to determine $\mathrm{NO}_{3}^{-}, \mathrm{SO}_{4}^{2-}$, and $\mathrm{Cl}^{-}$]. One replicate injection of standards was carried out after running 10 samples. The relative standard deviations between the duplicates were $10 \%$. Details of quality assurance/ quality control (QA/QC) are shown in Table S1.

The meteorological parameters, including ambient temperature, atmospheric pressure, relative humidity, wind speed, and wind direction, were obtained from an onboard automatic weather station. The weather situation, such as fog and cloud, was from onsite records. The information is shown in Fig S1. At each station, chlorophyll fluorescence (2-4 m below the sea surface) was obtained from a Seabird 911CTD (SeaBird Inc, Bellevue, Washington, United States). An inversion algorithm was used to fit size distributions of amines in different-sized particles (Dong et al. 2004; Yu and Yu 2012).

\section{Results and Discussion}

\section{a. Overview of particulate $D M A^{+}$and $T M A^{+}$in the marine and coastal atmospheres}

In each sample collected in the marine atmosphere over the Yellow Sea and the Bohai Sea, the total concentrations of $\mathrm{DMA}^{+}$or $\mathrm{TMA}^{+}$in particles with an aerodynamic diameter smaller than $11 \mu \mathrm{m}\left(\mathrm{PM}_{11}\right)$ are added together for discussion. The concentration of $\mathrm{DMA}^{+}$in $\mathrm{PM}_{11}\left(\left[\mathrm{DMA}^{+}\right]_{\mathrm{PM} 11}\right)$ was $4.4 \pm 3.7 \mathrm{nmol} \mathrm{m}^{-3}$ (mean plus or minus standard deviation) with the maximum $\left[\mathrm{DMA}^{+}\right]_{\mathrm{PM} 11}$ of $14.8 \mathrm{nmol} \mathrm{m}^{-3}$. The mean value of $\left[\mathrm{TMA}^{+}\right]_{\mathrm{PM} 11}\left(7.2 \pm 7.1 \mathrm{nmol} \mathrm{m}^{-3}\right)$ was almost double that of $\left[\mathrm{DMA}^{+}\right]_{\mathrm{PM} 11}$. The maximum $\left[\mathrm{TMA}^{+}\right]_{\mathrm{PM} 11}$ was $24.9 \mathrm{nmol} \mathrm{m}^{-3}$. The $\left[\mathrm{DMA}^{+}\right]$and $\left[\mathrm{TMA}^{+}\right]$in particles 
less than $1.1 \mu \mathrm{m}\left(\mathrm{PM}_{1.1}\right)$ accounted for approximately $60 \%$ of these ions in $\mathrm{PM}_{11}$ (Table 1), indicating that these ions were almost evenly distributed between submicron and supermicron sizes. These concentrations of $\left[\mathrm{DMA}^{+}\right]$and $\left[\mathrm{TMA}^{+}\right]$in particles of different size in this study were approximately one to three orders of magnitude larger than the values reported for various marine aerosol particles (Table 1).

In each sample collected at the coastal site, the total concentrations of $\mathrm{DMA}^{+}$or $\mathrm{TMA}^{+}$in atmospheric particles smaller than $10 \mu \mathrm{m}\left(\mathrm{PM}_{10}\right)$ are added together for comparison (Table 1). The $\left[\mathrm{DMA}^{+}\right]_{\mathrm{PM} 10}$ and $\left[\mathrm{TMA}^{+}\right]_{\mathrm{PM} 10}$ were $0.11 \pm 0.07$ and $0.09 \pm 0.05 \mathrm{nmol} \mathrm{m}^{-3}$, respectively. The concentrations were approximately two orders of magnitude smaller than the values in $\mathrm{PM}_{11}$ measured over the Yellow Sea and the Bohai Sea, but the concentrations were of the same order of magnitude as the concentrations reported in the literature (Table 1).

In the literature, fish emissions appear to be the strongest source of amines. For example, Namieśnik et al. (2003) measured DMA and TMA gases near a city market ( $2 \mathrm{~m}$ from a cluster of fish stands) in Gdańsk, Poland, and reported that the concentrations of DMA and TMA gases were as high as $3.1 \times 10^{6}$ and $1.3 \times$ $10^{6} \mathrm{nmol} \mathrm{m}^{-3}$, respectively. DMA and TMA gases can displace ammonium in atmospheric particles (Bzdek et al. 2010). Intensive ocean farming is distributed in many coastal areas of the Yellow Sea and the Bohai Sea. A large amount of $\mathrm{N}$-containing feed is used to improve seafood production, and this $\mathrm{N}$-containing feed might decompose and release a significant amount of amines to the atmosphere.

In the marine atmosphere, a good correlation between $\left[\mathrm{DMA}^{+}\right]_{\mathrm{PM} 11}$ and $\left[\mathrm{TMA}^{+}\right]_{\mathrm{PM} 11}$ was obtained with $R^{2}=$ 0.86 . Correlations were even better when the data were classified into two categories according to the mole ratio of $\mathrm{TMA}^{+} / \mathrm{DMA}^{+}$(i.e., $\mathrm{TMA}^{+} / \mathrm{DMA}^{+}$were about 1 in category 1 and about 2 in category 2) (Fig. 2a). In category 1 (Fig. 2a), the regression equation was $\left[\mathrm{TMA}^{+}\right]_{\mathrm{PM} 11}=0.97 \times\left[\mathrm{DMA}^{+}\right]_{\mathrm{PM} 11}$, with $R^{2}=0.96$. In category 2 (Fig. 2a), the regression equation was $\left[\mathrm{TMA}^{+}\right]_{\mathrm{PM} 11}=1.91 \times\left[\mathrm{DMA}^{+}\right]_{\mathrm{PM} 11}$, with $R^{2}=0.94$. The good correlations suggest that the observed $\mathrm{DMA}^{+}$ and $\mathrm{TMA}^{+}$may have the same origins. The mean values of $\left[\mathrm{TMA}^{+}\right]_{\mathrm{PM} 11}$ and $\left[\mathrm{DMA}^{+}\right]_{\mathrm{PM} 11}$ were $3.0 \pm 2.7$ and $3.3 \pm 2.4 \mathrm{nmol} \mathrm{m}^{-3}$ in category 1 , while the mean values were $10.5 \pm 7.8$ and $5.2 \pm 4.5 \mathrm{nmol} \mathrm{m}^{-3}$, respectively, in category 2 . The $\left[\mathrm{TMA}^{+}\right]_{\mathrm{PM} 11}$ in category 2 was significantly larger than the $\left[\mathrm{TMA}^{+}\right]_{\mathrm{PM} 11}$ in category 1 , with $95 \%$ confidence, but the difference was not significant for $\left[\mathrm{DMA}^{+}\right]_{\mathrm{PM} 11}$. As discussed later, the elevated levels of $\left[\mathrm{TMA}^{+}\right]_{\mathrm{PM} 11}$ and $\left[\mathrm{DMA}^{+}\right]_{\mathrm{PM} 11}$ in category 2 were mainly as a result of enhanced formation of these ions in submicron particles. In category 2 , both $\mathrm{TMA}^{+}$and $\mathrm{DMA}^{+}$in $\mathrm{PM}_{11}$ had a negative correlation with ambient temperature $\left(R^{2}=0.78-0.82, p<0.01\right)$, and approximately $60 \%$ of the samples were collected in the daytime. There was no significant correlation between the two ions and other meteorological factors, including wind speed, relative humidity, and atmospheric pressure. In category 1 , approximately $70 \%$ of the samples were collected at nighttime, and only approximately $30 \%$ of samples were collected in daytime. Both $\mathrm{TMA}^{+}$ and $\mathrm{DMA}^{+}$in $\mathrm{PM}_{11}$ had a positive correlation with wind speed $\left(R^{2}=0.70-0.76, p<0.01\right)$ and had no significant correlation with ambient temperature, relative humidity, and atmospheric pressure. Nighttime apparently had lower levels of TMA and DMA gases being released into the atmosphere, leading to smaller amounts of $\mathrm{TMA}^{+}$ and $\mathrm{DMA}^{+}$formed in the $\mathrm{PM}_{11}$. For both category 1 and category 2 , there were no significant correlations between the two ions and $\mathrm{Cl}^{-}$and between the two ions and pollutants such as $\mathrm{SO}_{4}^{2-}$ and $\mathrm{NO}_{3}^{-}$. In addition, the concentration of triethylamine $\left(\mathrm{TEA}^{+}\right)$in the $\mathrm{PM}_{11}$ was lower than the detection limit in this cruise period.

In the coastal atmosphere, the correlation between $\left[\mathrm{DMA}^{+}\right]_{\mathrm{PM} 10}$ and $\left[\mathrm{TMA}^{+}\right]_{\mathrm{PM} 10}$ was not significant, with $R^{2}=0.14(p>0.05)$. When two exceptions were removed (Fig. 2b), a significant correlation between $\left[\mathrm{DMA}^{+}\right]_{\mathrm{PM} 10}$ and $\left[\mathrm{TMA}^{+}\right]_{\mathrm{PM} 10}$ was obtained, with $R^{2}=$ $0.50(p<0.01)$. As presented later, size distributions of $\mathrm{DMA}^{+}$were quite different from the size distributions of $\mathrm{TMA}^{+}$in the atmosphere, and the difference can explain the poor correlation between $\left[\mathrm{DMA}^{+}\right]_{\mathrm{PM} 10}$ and $\left[\mathrm{TMA}^{+}\right]_{\mathrm{PM} 10}$.

\section{b. Spatial variations of $\left[D M A^{+}\right]_{P M 11}$ and $\left[T M A^{+}\right]_{P M 11}$ related to chlorophyll a fluorescence}

Many studies have shown that concentrations of $\mathrm{DMA}^{+}$and $\mathrm{TMA}^{+}$in ocean sediment, seawater, and marine atmospheres are correlated with biological activity or chlorophyll a concentrations (Calderón et al. 2007; Facchini et al. 2008a; Gibb et al. 1999a; Müller et al. 2009; Rinaldi et al. 2010; Wang and Lee 1994; Welsh 2000; Yang et al. 1994). We therefore examined spatial variations of $\left[\mathrm{DMA}^{+}\right]_{\mathrm{PM} 11}$ and $\left[\mathrm{TMA}^{+}\right]_{\mathrm{PM} 11}$ in relation to chlorophyll a fluorescence in surface seawater during this cruise (Figs. 1a,b). Higher levels of $\left[\mathrm{DMA}^{+}\right]_{\mathrm{PM} 11}$ and $\left[\mathrm{TMA}^{+}\right]_{\mathrm{PM} 11}$ were observed mainly over the ocean area close to the mouth of the Yangtze River. The ocean area suffered from severe eutrophication, and high concentrations of chlorophyll a were often observed (Tan et al. 2011). In addition, a few higher values of $\left[\mathrm{DMA}^{+}\right]_{\mathrm{PM} 11}$ and $\left[\mathrm{TMA}^{+}\right]_{\mathrm{PM} 11}$ were also detected in other areas of the Yellow Sea and the Bohai Sea. No decreasing trend for $\left[\mathrm{DMA}^{+}\right]_{\mathrm{PM} 11}$ and 


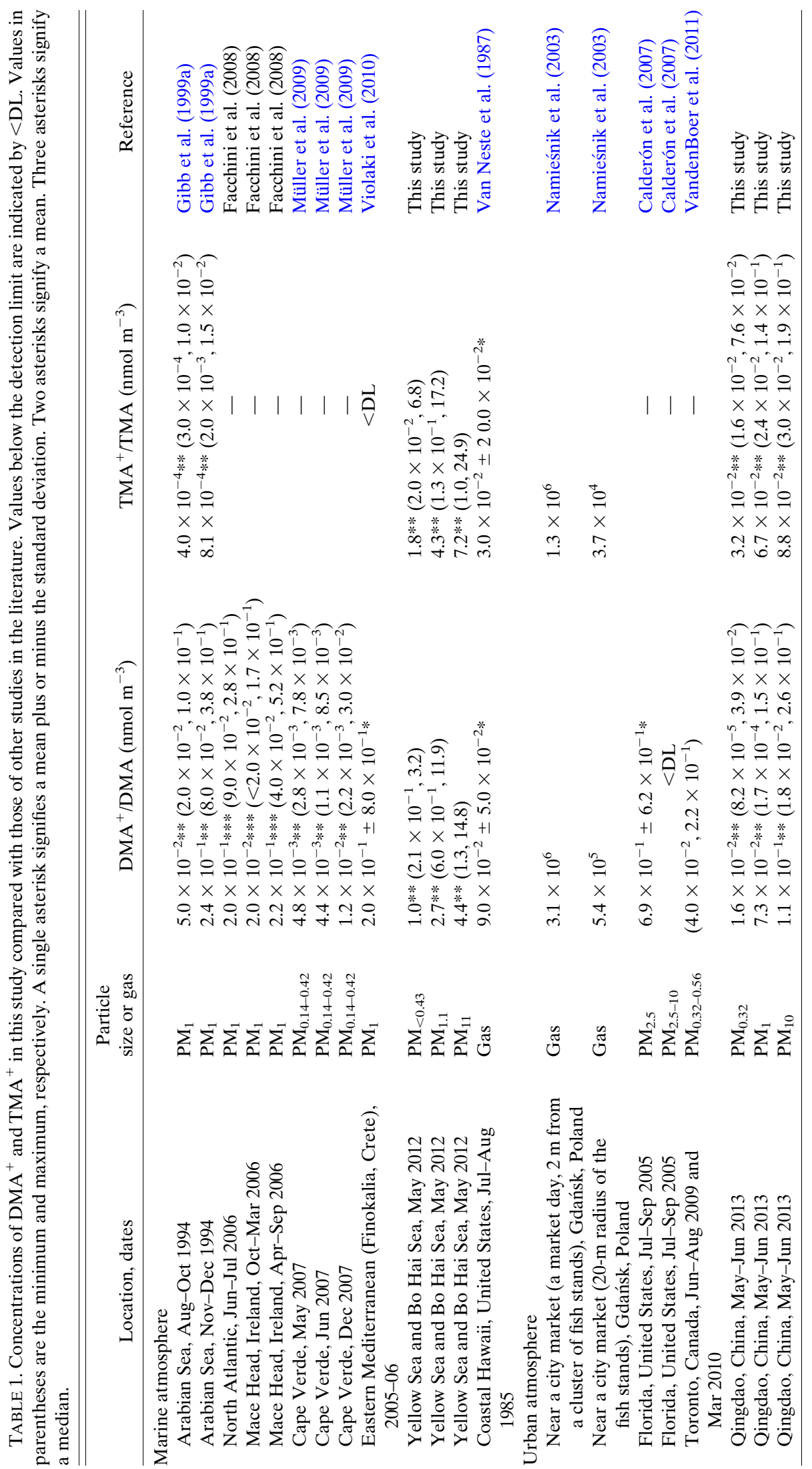



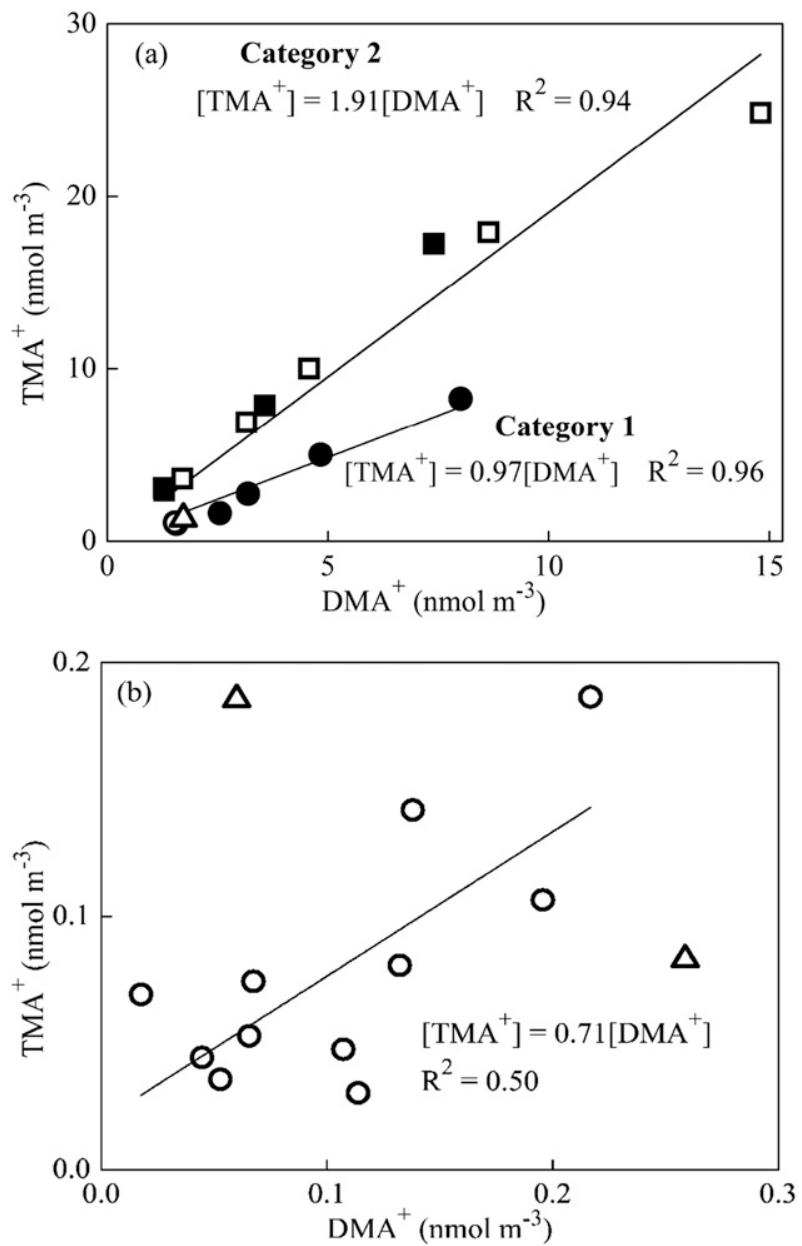

FIG. 2. Correlation between $\mathrm{DMA}^{+}$and $\mathrm{TMA}^{+}$in $\mathrm{PM}_{11}$. (a) Samples were collected in the marine atmosphere. The boxes represent samples with a mole ratio of $\mathrm{TMA}^{+}$to $\mathrm{DMA}^{+}$close to 2 , and the circles and triangle represents samples with a mole ratio of $\mathrm{TMA}^{+}$to $\mathrm{DMA}^{+}$close to 1 . The open and solid markers represent samples collected in the daytime and nighttime, respectively, and the open triangle represents a sample collected in both daytime and nighttime. (b) Samples were collected in the coastal atmosphere, and the correlation was calculated when two exceptions (triangles) were removed.

$\left[\mathrm{TMA}^{+}\right]_{\mathrm{PM} 11}$ was observed with increasing distance of the sampling of the oceanic area from the coastline. Lower levels of $\left[\mathrm{DMA}^{+}\right]_{\mathrm{PM} 11}$ and $\left[\mathrm{TMA}^{+}\right]_{\mathrm{PM} 11}$ were observed over the Yellow Sea between $33^{\circ}$ and $36^{\circ} \mathrm{N}$. The runoff water of the Yangtze River rarely reached the ocean area, where the nutrients that accumulated in the seawater during the winter were usually depleted in early spring after a few biogenic blooms (Liu et al. 2013).

Concentrations of chlorophyll-a were not available during the cruise campaign. Alternatively, chlorophyll a fluorescence values were used as a proxy for biological activity. A moderately good correlation was found between $\left[\mathrm{DMA}^{+}\right]_{\mathrm{PM} 11}$ and chlorophyll a fluorescence
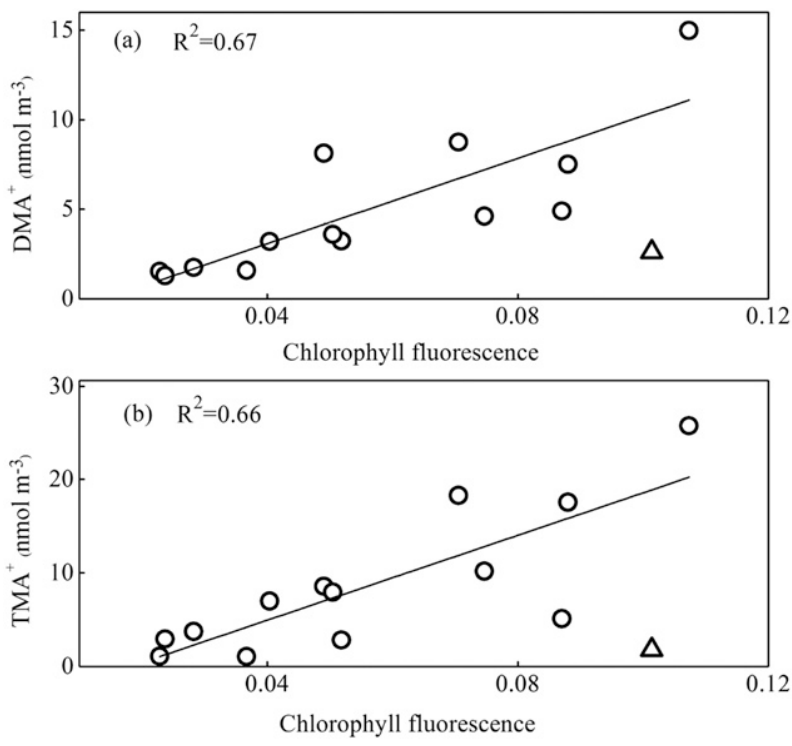

FIG. 3. Correlations of (a) $\mathrm{DMA}^{+}$and (b) $\mathrm{TMA}^{+}$with chlorophyll fluorescence. The open triangle represents a sample collected at nighttime on 19 May, and open circles represent the remaining samples. The open triangle was excluded to calculate $R^{2}$; the $R^{2}$ values are (a) 0.40 and (b) 0.37 when the open triangles are included. No chlorophyll fluorescence was available for two samples, and only 14 samples are shown.

values, with one exception measured in the nighttime on 19 May that was excluded (Fig. 3). The same is true for $\left[\mathrm{TMA}^{+}\right]_{\mathrm{PM} 11}$ when the $\left[\mathrm{TMA}^{+}\right]_{\mathrm{PM} 11}$ measured at the same period was removed. The moderately good correlations suggest that marine biological emissions were likely an important source of the observed $\mathrm{DMA}^{+}$and $\mathrm{TMA}^{+}$. When spatial variations of $\left[\mathrm{DMA}^{+}\right]_{\mathrm{PM} 11}$ and $\left[\mathrm{TMA}^{+}\right]_{\mathrm{PM} 11}$ were compared with spatial variations of $\left[\mathrm{NH}_{4}^{+}\right]_{\mathrm{PM} 11},\left[\mathrm{SO}_{4}^{2-}\right]_{\mathrm{PM} 11}$, and $\left[\mathrm{NO}_{3}^{-}\right]_{\mathrm{PM} 11}$ (Fig. 1c), the larger $\left[\mathrm{DMA}^{+}\right]_{\mathrm{PM} 11}$ and $\left[\mathrm{TMA}^{+}\right]_{\mathrm{PM} 11}$ were observed concurrently with the smaller $\left[\mathrm{NH}_{4}^{+}\right]_{\mathrm{PM} 11},\left[\mathrm{SO}_{4}^{2-}\right]_{\mathrm{PM} 11}$, and $\left[\mathrm{NO}_{3}^{-}\right]_{\mathrm{PM} 11}$, and vice versa. For example, the largest $\left[\mathrm{DMA}^{+}\right]_{\mathrm{PM} 11}$ and $\left[\mathrm{TMA}^{+}\right]_{\mathrm{PM} 1}$ occurred in the daytime of 2 May, when a strong wind was blowing from the northeast with an average wind speed of $9.0 \mathrm{~m} \mathrm{~s}^{-1}$ (Fig. S1a). The calculated airmass back trajectories showed the origin of air mass was also from the sea (Fig. S2) (Draxler and Rolph 2015; Rolph 2015). The high wind speed should substantially increase the airsea exchange flux for both gases and aerosol particles (Duan et al. 2013), and strong air-sea exchange might cause the high levels of $\left[\mathrm{DMA}^{+}\right]_{\mathrm{PM} 11}$ and $\left[\mathrm{TMA}^{+}\right]_{\mathrm{PM} 11}$. The northeast direction of the sampling area is the main body of the Yellow Sea, so less anthropogenic air pollution was expected (Shi et al. 2010). $\left[\mathrm{NH}_{4}^{+}\right]_{\mathrm{PM} 11},\left[\mathrm{SO}_{4}^{2-}\right]_{\mathrm{PM} 11}$, and $\left[\mathrm{NO}_{3}^{-}\right]_{\mathrm{PM} 11}$ in the sample were the smallest in the total of 16 samples. Higher concentrations of $\left[\mathrm{NH}_{4}^{+}\right]_{\mathrm{PM} 11}$, 
$\left[\mathrm{SO}_{4}^{2-}\right]_{\mathrm{PM} 11}$, and $\left[\mathrm{NO}_{3}^{-}\right]_{\mathrm{PM} 11}$ were observed over the Yellow Sea between $33^{\circ}$ and $36^{\circ} \mathrm{N}$, where $\left[\mathrm{DMA}^{+}\right]_{\mathrm{PM} 11}$ and $\left[\mathrm{TMA}^{+}\right]_{\mathrm{PM} 11}$ were lower. The wind direction and the calculated airmass back trajectories showed that the origin of air mass was also from the continent (Figs. S1a and S2). Moreover, the ratios of $\mathrm{DMA}^{+}$to $\mathrm{NH}_{4}^{+}$and $\mathrm{TMA}^{+}$ to $\mathrm{NH}_{4}^{+}$in $\mathrm{PM}_{11}$ in the marine atmosphere were over two orders of magnitude larger than those ratios in $\mathrm{PM}_{11}$ in the coastal atmosphere of Qingdao. All these results further reinforce our analysis: that is, these two ions observed in the atmospheric particles over the Yellow Sea and the Bohai Sea were overwhelmingly from marine sources other than the transport of $\mathrm{DMA}^{+}$and $\mathrm{TMA}^{+}$ from adjacent continents.

\section{c. Size distributions of $\mathrm{DMA}^{+}$and $\mathrm{TMA}^{+}$in the coastal atmosphere}

To gain insight on the complicated size distributions of $\mathrm{DMA}^{+}$and $\mathrm{TMA}^{+}$in the marine atmosphere, we first examined size distributions of the two ions in the coastal atmosphere (Fig. 4). Even in the coastal atmosphere, reports of size distributions of $\mathrm{DMA}^{+}$and $\mathrm{TMA}^{+}$are limited in the literature, and the modal structures of their mass concentration in atmospheric particles are not well understood. However, the modal structure of $\mathrm{NH}_{4}^{+}$in atmospheric particles and its corresponding formation mechanisms have been clearly established in the last decades (Ondov and Wexler 1998; Seinfeld and Pandis 2006; Yao et al. 2001; Yao and Zhang 2012a,b; Zhang et al. 2012). In continental atmospheres, amines and $\mathrm{NH}_{3}$ are conventionally assumed to come from the same sources. Thus, our analysis starts from size distributions of $\mathrm{NH}_{4}^{+}$in the coastal atmosphere (Fig. 4a). The analysis result is used to facilitate interpretation of origins and formation of $\mathrm{DMA}^{+}$and $\mathrm{TMA}^{+}$in particles of different sizes. When lognormal functions were used to fit the size distribution of $\mathrm{NH}_{4}^{+}$, the results showed that $\mathrm{NH}_{4}^{+}$generally showed two modes: that is, a dominant mode with a median mass aerodynamic diameter (MMAD) of $0.8 \pm 0.1 \mu \mathrm{m}$ and a minor mode with an MMAD of $0.2 \pm 0.1 \mu \mathrm{m}$, except in two lowerconcentration samples (Fig. S3). In the two lowconcentration samples collected on 20 May and 2 June, $\mathrm{NH}_{4}^{+}$had a dominant mode with MMAD at $0.4 \pm 0.1 \mu \mathrm{m}$, with a minor mode at $0.2 \pm 0.1 \mu \mathrm{m}$. In the literature (Ondov and Wexler1998; Rehbein et al. 2011; Seinfeld and Pandis 2006; Yao et al. 2001; Yao and Zhang 2012a,b; Zhang et al. 2012), the modes $0.2 \pm 0.1$ and $0.8 \pm 0.1 \mu \mathrm{m}$ are conventionally referred to as the condensation mode and droplet mode, respectively. The droplet mode is assumed to be as a result of cloud processing, and the mode $0.4 \pm 0.1 \mu \mathrm{m}$ is usually associated with primary combustion emissions (Ondov and Wexler 1998; Seinfeld and
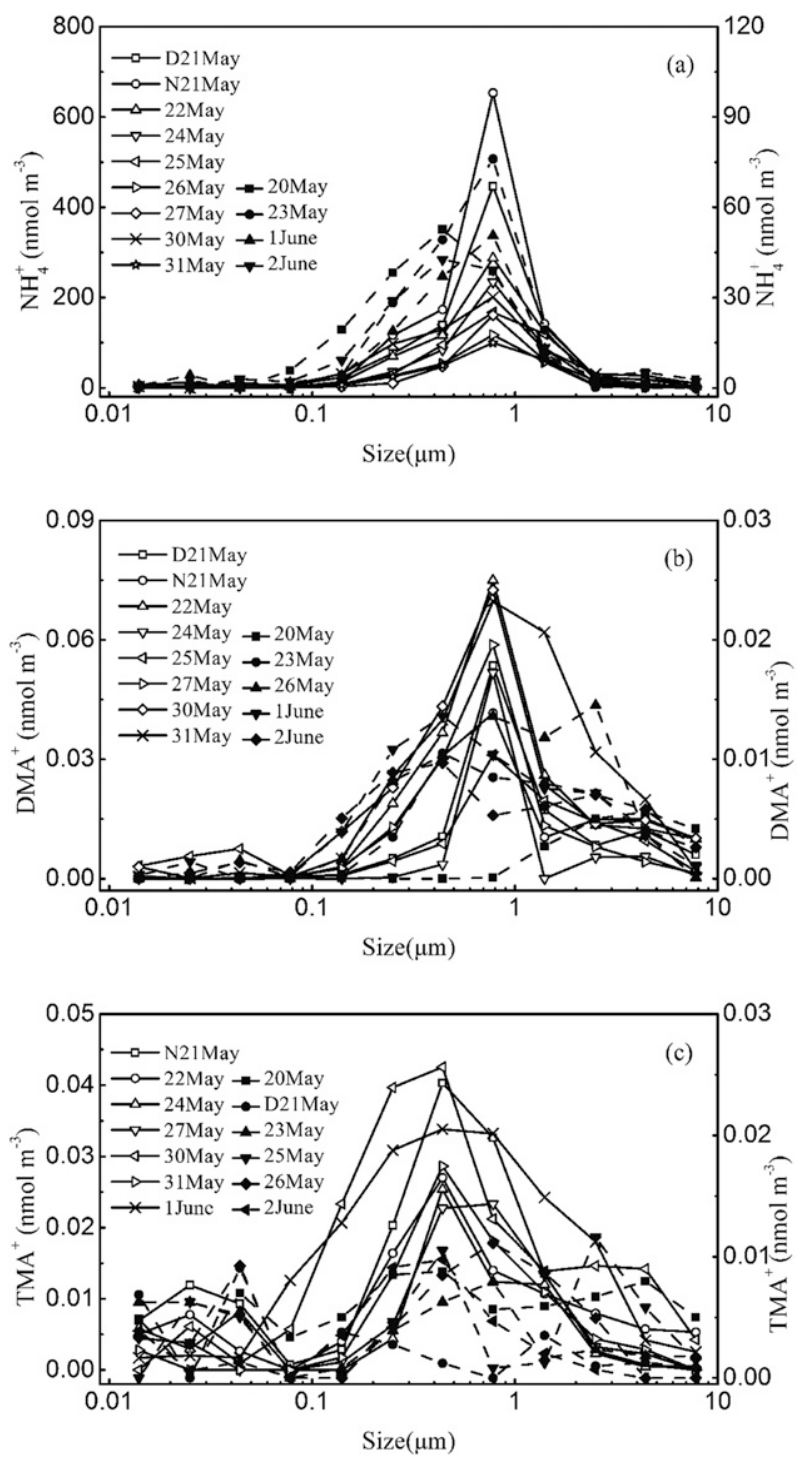

FIG. 4. Size distributions of (a) $\mathrm{NH}_{4}^{+}$, (b) $\mathrm{DMA}^{+}$, and (c) $\mathrm{TMA}^{+}$ in the coastal atmosphere on 20 May-2 Jun 2013. The letter before the date represents whether the sample was collected in the daytime (D) or in the nighttime (N). Higher concentrations are on the left $y$ axis and are represented by open markers. Lower concentrations are on the right $y$ axis and are represented by solid markers.

Pandis 2006). The droplet-mode aerosols can reside in the atmosphere for several days and may generate on the observational day and/or several days before.

Similar to $\mathrm{NH}_{4}^{+}, \mathrm{DMA}^{+}$in eight sets of samples with higher concentrations had a dominant mode at $0.8 \pm$ $0.1 \mu \mathrm{m}$ (Figs. $4 \mathrm{~b}$ and S4). A condensation mode at $0.2 \pm$ $0.1 \mu \mathrm{m}$ was also observed in many samples (Fig. S4). Unlike $\mathrm{NH}_{4}^{+}, \mathrm{DMA}^{+}$had a coarse mode with MMAD at $3 \pm 1 \mu \mathrm{m}$. The coarse mode was unlikely to be associated with interactions between gases and sea-salt/crustal 
aerosols, because the interactions led to a coarse mode at $5 \pm 1 \mu \mathrm{m}$ (Fig. S5a). The single-particle studies in marine coastal atmospheres by Gaston et al. (2013) and Healy et al. (2015) also indicated that sea salt and marine biogenic aminium species were externally mixed. As reported, the abundance of microbial bioaerosols in the atmosphere at the coastal site had a mode at $2-4 \mu \mathrm{m}(\mathrm{Yu}$ et al. 2013). Considering that microbial material can decompose organics to produce amines (Ge et al. 2011a), and no other source or pathway can explain the observed coarse mode of $\mathrm{DMA}^{+}$to the best of our knowledge, we speculated that the coarse mode of $\mathrm{DMA}^{+}$could be associated with bioaerosols in the atmosphere. In five sets of lower-concentration samples (Figs. 4b and S4), the concentration of $\mathrm{DMA}^{+}$in the coarse mode at $3 \pm 1 \mu \mathrm{m}$ was comparable to that in the major mode in submicron size. In three of five sets of lower-concentration samples, the major mode of $\mathrm{DMA}^{+}$in submicron size had an MMAD at $0.4 \pm 0.1 \mu \mathrm{m}$. In one of five sets of lower-concentration samples, the major submicron mode of $\mathrm{DMA}^{+}$still had MMAD at $0.8 \mu \mathrm{m}$. For the remaining set of samples, the submicron mode of $\mathrm{DMA}^{+}$was absent.

$\mathrm{TMA}^{+}$had a dominant mode at $0.4 \pm 0.1 \mu \mathrm{m}$ in seven sets of samples with higher concentrations (Figs. $4 \mathrm{c}$ and S6). In the corresponding samples, $\mathrm{NH}_{4}^{+}$and $\mathrm{DMA}^{+}$ had a dominant mode at $0.8 \pm 0.1 \mu \mathrm{m}$. The mode of $\mathrm{TMA}^{+}$at $0.4 \pm 0.1 \mu \mathrm{m}$ could be associated with combustion sources (e.g., on-road vehicles could emit amines and aminium salts) (Ge et al. 2011a). In the samples collected on 22 and 24 May and 1 June, a broad peak of $\left[\mathrm{TMA}^{+}\right]$was observed in the $0.3-2-\mu \mathrm{m}$ size range. Pratt et al. (2009) and Gaston et al. (2013) proposed that $\mathrm{TMA}^{+}$at the size range may be related to secondary coatings on combustion particles. Our fitting results showed two modes at $0.4 \pm 0.1$ and $1.1 \pm 0.2 \mu \mathrm{m}$ in the size range. The mode at $1.1 \pm 0.2 \mu \mathrm{m}$ could also be because of cloud processing. Multiple solutions for the types of size distribution could be found theoretically, and our fitting results are not a unique solution. The condensation mode of $\mathrm{TMA}^{+}$was obtained in only four sets of samples, but $\mathrm{TMA}^{+}$apparently had a mode with the MMAD less than $0.05 \mu \mathrm{m}$. The coarse mode of $\mathrm{TMA}^{+}$ at $3 \pm 1 \mu \mathrm{m}$ was also obtained in four sets of samples (Figs. 4c and S6). In the six sets of samples with lower concentrations of $\mathrm{TMA}^{+}$(Fig. 4c), size distributions of $\mathrm{TMA}^{+}$were irregular. At such low concentrations, size distributions of $\mathrm{TMA}^{+}$may not be physically meaningful as a result of large uncertainties in the chemical analysis.

\section{d. Size distributions of $\mathrm{DMA}^{+}$and $T M A^{+}$in the marine atmosphere}

In the marine atmosphere, all particles smaller than $0.43 \mu \mathrm{m}$ were collected on the last stage of the filter, and
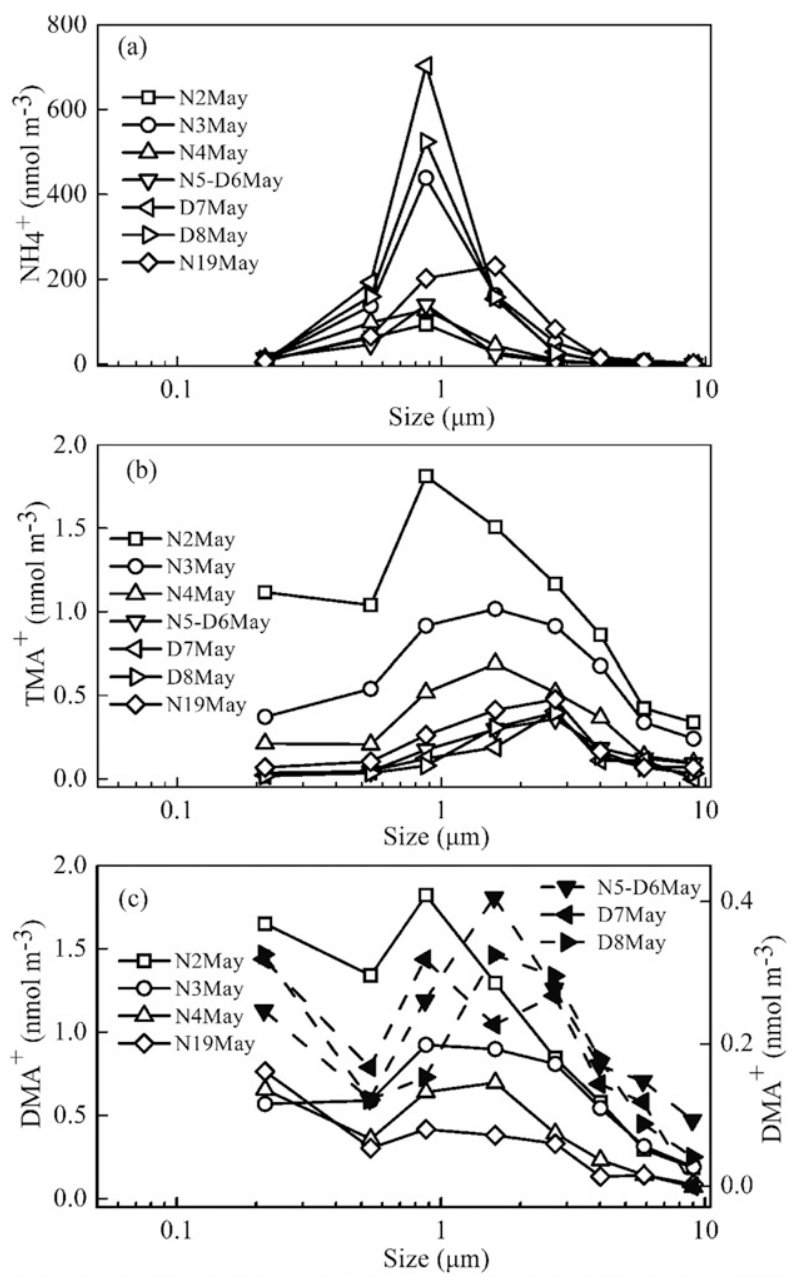

FIG. 5. Size distributions of (a) $\mathrm{NH}_{4}^{+}$, (b) $\mathrm{TMA}^{+}$, and (c) $\mathrm{DMA}^{+}$ in category 1 over the seas. The letter before the date represents whether the sample was collected in the daytime (D) or in the nighttime $(\mathrm{N})$. Higher concentrations are on the left $y$ axis and are represented by open markers. Lower concentrations are on the right $y$ axis and are represented by solid markers.

the corresponding $d C / d \log D p$ (change in concentration with particle sizes) cannot be calculated. We fitted the size distribution of chemical species only in particles larger than $0.43 \mu \mathrm{m}$. For category 1, the fitting results showed that $\mathrm{NH}_{4}^{+}$generally had a unique mode with the MMAD at $0.9 \pm 0.1 \mu \mathrm{m}$, except for one sample collected at nighttime on 19 May (Figs. 5 and S7). In the exception, a heavy fog occurred for 8 of the 11 sampling hours (Fig. S1b). The measured $\mathrm{NH}_{4}^{+}$had two modes at 0.9 and $1.6 \mu \mathrm{m}$ (Fig. S7). Fog processing of secondary ions usually forms a mode at $1-2 \mu \mathrm{m}$ (Ondov and Wexler1998; Yao and Zhang 2012a).

When the mass size distributions of $\mathrm{TMA}^{+}$in category 1 were examined (Fig. S8), two modes with the MMAD at $1.0 \pm 0.2$ and $3 \pm 1 \mu \mathrm{m}$ were obtained for all 
samples. In four sets of samples with lower $\left[\mathrm{TMA}^{+}\right]$, the mode of $\mathrm{TMA}^{+}$at $5 \pm 1 \mu \mathrm{m}$ was obtained, and it was likely associated with sea-salt aerosols (Fig. S9). Similar to $\mathrm{TMA}^{+}, \mathrm{DMA}^{+}$also had two modes with the MMAD at $0.9 \pm 0.2$ and $3 \pm 1 \mu \mathrm{m}$ (Fig. S10). In two sets of samples, the mode of $\mathrm{DMA}^{+}$at $5 \pm 1 \mu \mathrm{m}$ was obtained. The mode of $\mathrm{TMA}^{+}$at $0.9 \pm 0.2 \mu \mathrm{m}$ and the mode of $\mathrm{DMA}^{+}$at $1.0 \pm 0.2 \mu \mathrm{m}$ were possibly as a result of cloud processing, while the mode of $\mathrm{TMA}^{+}$and $\mathrm{DMA}^{+}$at $3 \pm$ $1 \mu \mathrm{m}$ was likely to be associated with microbial bioaerosols. It is interesting that moderately good negative correlations were obtained between oxalate and the two ions in the particles at the 2.1-3.3- $\mu \mathrm{m}$ size range with $R^{2}=0.64-0.68$ and $P<0.05$, but no significant correlations between them were found at any other size particles. The negative corrections also suggested that the strong biogenic decomposition of organic carbon and production of ammonium ions likely occurred at the size range. The abundance of marine bioaerosols was also reported to have a mode at $2-4 \mu \mathrm{m}$ ( $\mathrm{Li}$ et al. 2011). In most samples, $\left[\mathrm{DMA}^{+}\right]$in particles smaller than $0.43 \mu \mathrm{m}\left(\mathrm{PM}_{0.43}\right)$ was larger than $\left[\mathrm{DMA}^{+}\right]$in $0.43-0.65-\mu \mathrm{m}$ particles (Fig. $5 \mathrm{c}$ ). Müller et al. (2009) reported that the highest concentrations of $\mathrm{DMA}^{+}$and $\mathrm{DEA}^{+}$were found mostly in 0.14 $0.42-\mu \mathrm{m}$ atmospheric particles collected at the Cape Verde Islands in the North Atlantic Ocean. Facchini et al. (2008b) found high concentrations of $\mathrm{DMA}^{+}$and $\mathrm{DEA}^{+}$ in $0.25-0.5-\mu \mathrm{m}$ atmospheric particles over the North Atlantic. Facchini et al. (2008a) also reported that the bubble-bursting aerosols likely contained a negligible amount of $\mathrm{DMA}^{+}$, even during the period with high biogenic activity, and $\mathrm{DMA}^{+}$in submicron particles was mainly from gas-particle reactions. The elevated [DMA $\left.{ }^{+}\right]$ in $\mathrm{PM}_{0.43}$ of this study could also be associated with gasparticle partitioning rather than primary emissions.

In category 2 , both $\mathrm{TMA}^{+}$and $\mathrm{DMA}^{+}$had two modes with the MMAD at $0.8 \pm 0.1$ and $3 \pm 1 \mu \mathrm{m}$, respectively (Figs. 6, S11, and S12). In two sets of samples, both $\mathrm{TMA}^{+}$and $\mathrm{DMA}^{+}$also had a coarse mode with the MMAD at $5 \pm 1 \mu \mathrm{m}$. The elevated $\left[\mathrm{TMA}^{+}\right]$in $\mathrm{PM}_{0.43}$ relative to the $\left[\mathrm{TMA}^{+}\right]$in $0.43-0.65-\mu \mathrm{m}$ particles was observed in all samples of category 2 . The elevated $\left[\mathrm{DMA}^{+}\right]$in $\mathrm{PM}_{0.43}$ was also observed in most samples in category 2 . The elevation could also be due to enhanced gas-particle partitioning. Both $\mathrm{TMA}^{+}$and $\mathrm{DMA}^{+}$in $\mathrm{PM}_{0.43}$ had moderately good negative correlations with ambient temperature, with $R^{2}=0.82-0.83$ and $P<0.01$, supporting the gas-particle formation of these ions. Although positive correlations between the two ions and wind speed were obtained, $P$ was larger: 0.05 .

To quantify the contributions of $\mathrm{TMA}^{+}$and $\mathrm{DMA}^{+}$in different-sized particles to the total of these ions in $\mathrm{PM}_{11}$, we first calculated the contributions of particles
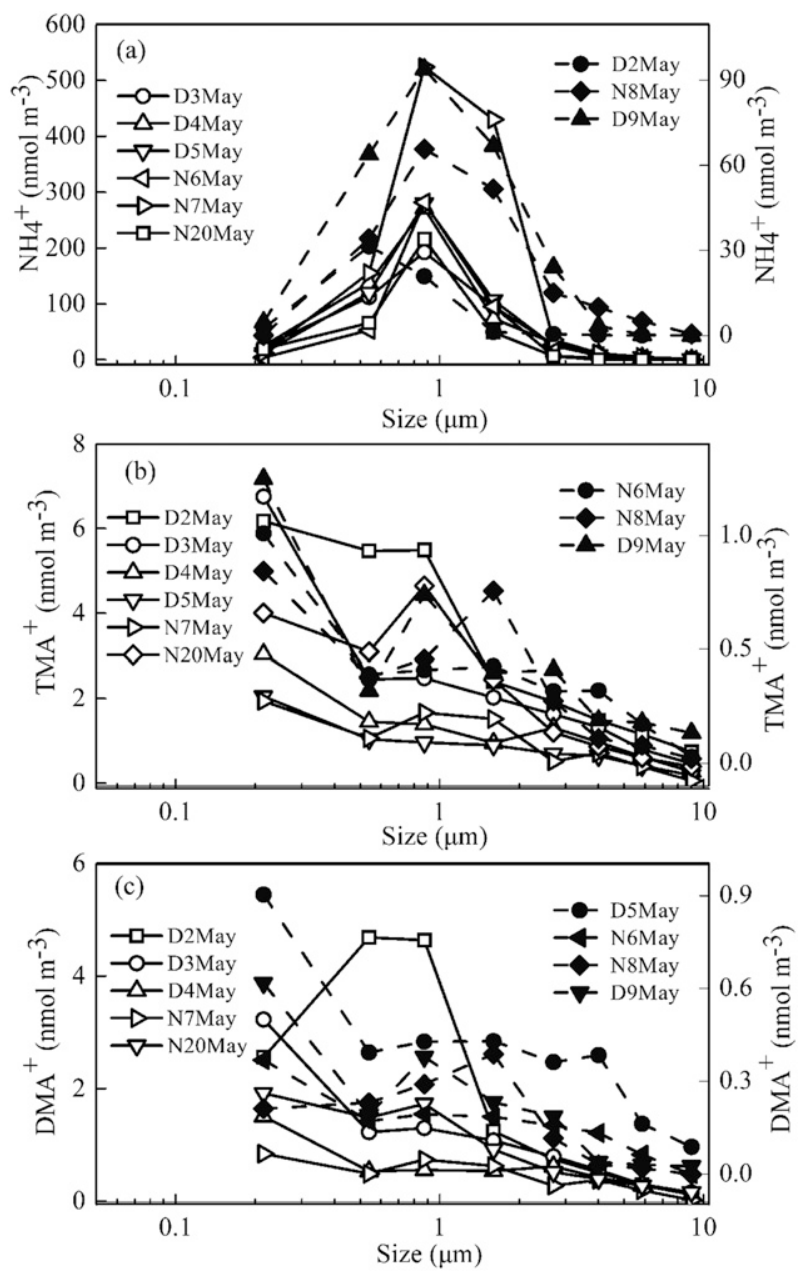

FIG. 6. Size distributions of (a) $\mathrm{NH}_{4}^{+}$, (b) $\mathrm{TMA}^{+}$, and (c) $\mathrm{DMA}^{+}$ in category 2 over the seas. The letter before the date represents whether the sample was collected in the daytime (D) or in the nighttime $(\mathrm{N})$. Higher concentrations are on the left $y$ axis and are represented by open markers. Lower concentrations are on the right $y$ axis and are represented by solid markers.

smaller than $43 \mu \mathrm{m}$ and particles that were $0.43 \mu \mathrm{m}$ or larger (Table 2). In category $1,\left[\mathrm{DMA}^{+}\right]$and $\left[\mathrm{TMA}^{+}\right]$in $\mathrm{PM}_{0.43}$ accounted for $20 \% \pm 6 \%$ and $6 \% \pm 4 \%$ of the particles in $\mathrm{PM}_{11}$. Because of enhanced gas-particle partitioning in category $2,\left[\mathrm{DMA}^{+}\right]$and $\left[\mathrm{TMA}^{+}\right]$in $\mathrm{PM}_{0.43}$ accounted for approximately one-third of the $\left[\mathrm{DMA}^{+}\right]$and $\left[\mathrm{TMA}^{+}\right]$in $\mathrm{PM}_{11}$. For $\geq 0.43-\mu \mathrm{m}$ that were $0.43 \mu \mathrm{m}$ or larger, $\left[\mathrm{DMA}^{+}\right]$and $\left[\mathrm{TMA}^{+}\right]$had three contributors. Cloud/fog processing and bioaerosols are two major contributors for both category 1 and category 2 , and they contributed approximately $70 \%-90 \%$ of the $\left[\mathrm{DMA}^{+}\right]$and $\left[\mathrm{TMA}^{+}\right]$in $\mathrm{PM}_{11}$. The $\left[\mathrm{DMA}^{+}\right]$and $\left[\mathrm{TMA}^{+}\right]$associated with sea-salt aerosols yielded a minor contribution to the $\left[\mathrm{DMA}^{+}\right]$and $\left[\mathrm{TMA}^{+}\right]$in $\mathrm{PM}_{11}$ in categories 1 and 2 (Table 2). 
TABLE 2. The contribution of different secondary and primary sources to the observed $\mathrm{DMA}^{+}$and $\mathrm{TMA}^{+}$in $\mathrm{PM}_{11}$. Values are shown as the mean plus or minus the standard deviation.

\begin{tabular}{llcccc}
\hline \hline & & & \multicolumn{1}{c}{$\mathrm{PM}_{0.43-11}$} \\
\cline { 4 - 5 } Category & Species & $\mathrm{PM}_{0.43}$ & Droplet mode & Bioaerosols & Sea-salt aerosols \\
\hline \multirow{2}{*}{1} & $20 \% \pm 6 \%$ & $43 \% \pm 11 \%$ & $37 \% \pm 14 \%$ & $1 \% \pm 2 \%$ \\
& $\mathrm{DMA}^{+}$ & $6 \% \pm 4 \%$ & $36 \% \pm 7 \%$ & $54 \% \pm 6 \%$ & $4 \% \pm 6 \%$ \\
2 & $\mathrm{TMA}^{+}$ & $27 \% \pm 8 \%$ & $53 \% \pm 15 \%$ & $19 \% \pm 9 \%$ & $0 \%$ \\
& $\mathrm{DMA}^{+}$ & $30 \% \pm 5 \%$ & $45 \% \pm 9 \%$ & $23 \% \pm 7 \%$ & $2 \% \pm 4 \%$ \\
\hline
\end{tabular}

\section{e. Role of $\mathrm{DMA}^{+}$and $\mathrm{TMA}^{+}$in neutralizing acidic species in submicron particles}

To evaluate the role of $\mathrm{TMA}^{+}$and $\mathrm{DMA}^{+}$in neutralizing acidic species, the mole ratios of $\left(\mathrm{TMA}^{+}+\right.$ $\mathrm{DMA}^{+}$) to $\mathrm{NH}_{4}^{+}$were calculated in submicron particles of different sizes. For category 1 , the ratios were less than 0.02 in particles at the size of $0.43-0.65$ and $0.65-$ $1.1 \mu \mathrm{m}$. The low ratios suggested that $\mathrm{TMA}^{+}$and $\mathrm{DMA}^{+}$yielded a negligible contribution to neutralize acidic species when compared to $\mathrm{NH}_{4}^{+}$. The ratio in $\mathrm{PM}_{0.43}$ was less than 0.12 , except for one sample collected at nighttime on 2 May. In the exception, the ratio was 0.29 . The large ratio suggests that $\left(\mathrm{TMA}^{+}+\right.$ $\mathrm{DMA}^{+}$) may play an important role in neutralizing acidic species in $\mathrm{PM}_{0.43}$ of the sample.

For category 2, the ratios of $\left(\mathrm{TMA}^{+}+\mathrm{DMA}^{+}\right)$to $\mathrm{NH}_{4}^{+}$were less than 0.07 in particles at the sizes $0.43-$ 0.65 and $0.65-1.1 \mu \mathrm{m}$, excluding one sample collected in the daytime on 2 May. In the exception, the ratios of $\left(\mathrm{TMA}^{+}+\mathrm{DMA}^{+}\right)$to $\mathrm{NH}_{4}^{+}$were 0.32 in particles at the size $0.43-0.65 \mu \mathrm{m}$ and 0.49 in particles at the size $0.65-$ $1.1 \mu \mathrm{m}$. In $\mathrm{PM}_{0.43}$, the ratios of $\left(\mathrm{TMA}^{+}+\mathrm{DMA}^{+}\right)$to $\mathrm{NH}_{4}^{+}$varied from 0.18 to 3.4, with a mean value of 0.7 . These large ratios strongly suggest that $\left(\mathrm{TMA}^{+}+\right.$ $\left.\mathrm{DMA}^{+}\right)$in $\mathrm{PM}_{0.43}$ may have a significant contribution in neutralizing acidic species and cannot be ignored.

As a comparison, we also calculated the ratios of $\left(\mathrm{TMA}^{+}+\mathrm{DMA}^{+}\right)$to $\mathrm{NH}_{4}^{+}$in different-sized particles in the coastal atmosphere. All ratios were less than 0.02, indicating that $\left(\mathrm{TMA}^{+}+\mathrm{DMA}^{+}\right.$) have a negligible contribution in neutralizing acidic species in the coastal atmosphere.

\section{Conclusions}

Overall, the concentrations of $\mathrm{TMA}^{+}$and $\mathrm{DMA}^{+}$in atmospheric particles over the Yellow Sea and the Bohai Sea were much larger than the concentrations of $\mathrm{TMA}^{+}$and $\mathrm{DMA}^{+}$in coastal and marine aerosol particles reported in the literature. The concentrations of $\mathrm{TMA}^{+}$and $\mathrm{DMA}^{+}$and the ratios of $\mathrm{DMA}^{+}$to $\mathrm{NH}_{4}^{+}$ and $\mathrm{TMA}^{+}$to $\mathrm{NH}_{4}^{+}$in $\mathrm{PM}_{11}$ over the two seas were two to three orders of magnitude larger than those in $\mathrm{PM}_{10}$ in the coastal atmosphere of Qingdao. A large concentration gradient of the two ions was observed in the marine atmospheric particles, associated with varying chlorophyll fluorescence measured in the two seas. All these results implied that these two ions observed in the marine atmosphere were overwhelmingly from marine biogenic sources.

Cloud/fog processing and bioaerosols were likely the two major contributors to the observed $\left[\mathrm{TMA}^{+}\right]$and $\left[\mathrm{DMA}^{+}\right]$in $\mathrm{PM}_{11}$, followed by gas-particle partitioning and sea-salt aerosols. $\mathrm{TMA}^{+}$and $\mathrm{DMA}^{+}$possibly played an important role in neutralizing acidic species in $\mathrm{PM}_{0.43}$ during the period with high biogenic activity. All of these observations indicated that marginal seas suffering severe eutrophication, such as the Yellow Sea and the Bohai Sea, can be one of the strongest emission sources of DMA and TMA gases on Earth and are highly important for the study of the atmospheric chemistry of amines.

Acknowledgments. The study is supported by grants from the National Natural Science Foundation of China (NFSC; 41176099 and 41149901) and the National Program on Key Basic Research Project (973 Program; 2014CB953700). The authors gratefully acknowledge the NOAA Air Resources Laboratory (ARL) for providing the HYSPLIT transport and dispersion model and READY website (http://www.ready.noaa.gov) used in this publication.

\section{REFERENCES}

Bzdek, B. R., D. P. Ridge, and M. V. Johnston, 2010: Amine exchange into ammonium bisulfate and ammonium nitrate nuclei. Atmos. Chem. Phys., 10, 3495-3503, doi:10.5194/ acp-10-3495-2010.

Calderón, S. M., N. D. Poor, and S. W. Campbell, 2007: Estimation of the particle and gas scavenging contributions to wet deposition of organic nitrogen. Atmos. Environ., 41, 4281-4290, doi:10.1016/j.atmosenv.2006.06.067.

Carpenter, L. J., S. D. Archer, and R. Beale, 2012: Oceanatmosphere trace gas exchange. Chem. Soc. Rev., 41, 64736506, doi:10.1039/c2cs35121h. 
Dong, Y., M. D. Hays, N. D. Smith, and J. S. Kinsey, 2004: Inverting cascade impactor data for size-resolved characterization of fine particulate source emissions. J. Aerosol Sci., 35, 14971512, doi:10.1016/j.jaerosci.2004.07.002.

Draxler, R. R., and G. D. Rolph, 2015: HYSPLIT_Hybrid Single Particle Lagrangian Integrated Trajectory Model. NOAA Air Resources Laboratory, accessed April 2015. [Available online at http://www.arl.noaa.gov/HYSPLIT.php.]

Duan, Z., H. Gao, Z. Gao, R. Wang, Y. Xue, and X. Yao, 2013: An approach to minimizing artifacts caused by cross-sensitivity in the determination of air-sea $\mathrm{CO}_{2}$ flux using the eddycovariance technique. Bound.-Layer Meteor., 148, 227-239, doi:10.1007/s10546-013-9814-1.

Facchini, M. C., and Coauthors, 2008a: Important source of marine secondary organic aerosol from biogenic amines. Environ. Sci. Technol., 42, 9116-9121, doi:10.1021/es8018385.

— dominated by insoluble organic colloids and aggregates. Geophys. Res. Lett., 35, L17814, doi:10.1029/2008GL034210.

Gaston, C. J., P. K. Quinn, T. S. Bates, J. B. Gilman, D. M. Bon, W. C. Kuster, and K. A. Prather, 2013: The impact of shipping, agricultural, and urban emissions on single particle chemistry observed aboard the R/V Atlantis during CalNex. J. Geophys. Res. Atmos., 118, 5003-5017, doi:10.1002/jgrd.50427.

Ge, X., A. S. Wexler, and S. L. Clegg, 2011a: Atmospheric aminesPart I. A review. Atmos. Environ., 45, 524-546, doi:10.1016/ j.atmosenv.2010.10.012.

$\_,-$, and — 2011b: Atmospheric amines_-Part II. Thermodynamic properties and gas/particle partitioning. Atmos. Environ., 45, 561-577, doi:10.1016/j.atmosenv.2010.10.013.

Gibb, S. W., R. F. C. Mantoura, and P. S. Liss, 1999a: Oceanatmosphere exchange and atmospheric speciation of ammonia and methylamines in the region of the NW Arabian Sea. Global Biogeochem. Cycles, 13, 161-178, doi:10.1029/ $98 \mathrm{~GB} 00743$.

,,--- , and R. G. Barlow, 1999b: Distributions and biogeochemistries of methylamines and ammonium in the Arabian Sea. Deep-Sea Res. II, 46, 593-615, doi:10.1016/ S0967-0645(98)00119-2.

Gorzelska, K., and J. N. Galloway, 1990: Amine nitrogen in the atmospheric environment over the North Atlantic Ocean. Global Biogeochem. Cycles, 4, 309-333, doi:10.1029/ GB004i003p00309.

Healy, R. M., and Coauthors, 2015: Single-particle speciation of alkylamines in ambient aerosol at five European sites. Anal. Bioanal. Chem., doi:10.1007/s00216-014-8092-1, in press.

Kulmala, M., and Coauthors, 2013: Direct observations of atmospheric aerosol nucleation. Science, 339, 943-946, doi:10.1126/ science. 1227385 .

Li, M., J. Qi, H. Zhang, S. Huang, L. Li, and D. Gao, 2011: Concentration and size distribution of bioaerosols in an outdoor environment in the Qingdao coastal region. Sci. Total Environ., 409, 3812-3819, doi:10.1016/j.scitotenv.2011.06.001.

Liu, Y., T. R. Zhang, J. H. Shi, H. W. Gao, and X. H. Yao, 2013: Responses of chlorophyll a to added nutrients, Asian dust, and rainwater in an oligotrophic zone of the Yellow Sea: Implications for promotion and inhibition effects in an incubation experiment. J. Geophys. Res. Biogeosci., 118, 1763-1772, doi:10.1002/2013JG002329.

Milne, P. J., and R. G. Zika, 1993: Amino acid nitrogen in atmospheric aerosols: Occurrence, sources and photochemical modification. J. Atmos. Chem., 16, 361-398, doi:10.1007/ BF01032631.
Müller, C., Y. Iinuma, J. Karstensen, D. V. Pinxteren, S. Lehmann, T. Gnauk, and H. Herrmann, 2009: Seasonal variation of aliphatic amines in marine sub-micrometer particles at the Cape Verde islands. Atmos. Chem. Phys., 9, 9587-9597, doi:10.5194/ acp-9-9587-2009.

Myriokefalitakis, S., and Coauthors, 2010: Global modeling of the oceanic source of organic aerosols. Adv. Meteor., 2010, 939171, doi:10.1155/2010/939171.

Namieśnik, J., A. Jastrzebska, and B. Zygmunt, 2003: Determination of volatile aliphatic amines in air by solid-phase microextraction coupled with gas chromatography with flame ionization detection. J. Chromatogr., A1016, 1-9, doi:10.1016/ S0021-9673(03)01296-2.

Ondov, J. M., and A. S. Wexler, 1998: Where do particulate toxins reside? An improved paradigm for the structure and dynamics of the urban mid-Atlantic aerosol. Environ. Sci. Technol., 32, 2547-2555, doi:10.1021/es971067y.

Pratt, K. A., L. E. Hatch, and K. A. Prather, 2009: Seasonal volatility dependence of ambient particle phase amines. Environ. Sci. Technol., 43, 5276-5281, doi:10.1021/es803189n.

Rehbein, P. J., C. Jeong, M. L. McGuire, X. Yao, J. C. Corbin, and G. J. Evans, 2011: Cloud and fog processing enhanced gas-toparticle partitioning of trimethylamine. Environ. Sci. Technol., 45, 4346-4352, doi:10.1021/es1042113.

Rinaldi, M., and Coauthors, 2010: Primary and secondary organic marine aerosol and oceanic biological activity: Recent results and new perspectives for future studies. Adv. Meteor., 2010, 310682, doi: $10.1155 / 2010 / 310682$.

Rolph, G. D., 2015: Real-time Environmental Applications and Display System (READY). NOAA Air Resources Laboratory, accessed April 2015. [Available online at http://www. ready.noaa.gov.]

Schade, G. W., and P. J. Crutzen, 1995: Emission of aliphatic amines from animal husbandry and their reactions: Potential source of $\mathrm{N}_{2} \mathrm{O}$ and HCN. J. Atmos. Chem., 22, 319-346, doi:10.1007/BF00696641.

Seinfeld, J. H., and S. N. Pandis, 2006: Atmospheric Chemistry and Physics: From Air Pollution to Climate Change. John Wiley and Sons, $1232 \mathrm{pp}$.

Shi, J., H. Gao, J. Qi, J. Zhang, and X. Yao, 2010: Sources, compositions, and distributions of water-soluble organic nitrogen in aerosols over the China Sea. J. Geophys. Res., 115, D17303, doi:10.1029/2009JD013238.

Smith, J. N., and Coauthors, 2010: Observations of aminium salts in atmospheric nanoparticles and possible climatic implications. Proc. Natl. Acad. Sci. USA, 107, 6634-6639, doi:10.1073/ pnas.0912127107.

Sorooshian, A., and Coauthors, 2009: On the link between ocean biota emissions, aerosol, and maritime clouds: Airborne, ground, and satellite measurements off the coast of California. Global Biogeochem. Cycles, 23, GB4007, doi:10.1029/ 2009GB003464.

Tan, S. C., G. Y. Shi, J. H. Shi, H. W. Gao, and X. Yao, 2011: Correlation of Asian dust with chlorophyll and primary productivity in the coastal seas of China during the period from 1998 to 2008. J. Geophys. Res., 116, G02029, doi:10.1029/2010JG001456.

VandenBoer, T. C., A. Petroff, M. Z. Markovic, and J. G. Murphy, 2011: Size distribution of alkyl amines in continental particulate matter and their online detection in the gas and particle phase. Atmos. Chem. Phys., 11, 4319-4332, doi:10.5194/acp-11-4319-2011.

Van Neste, A., R. A. Duce, and C. Lee, 1987: Methylamines in the marine atmosphere. Geophys. Res. Lett., 14, 711-714, doi:10.1029/GL014i007p00711. 
Violaki, K., and N. Mihalopoulos, 2010: Water-soluble organic nitrogen (WSON) in size-segregated atmospheric particles over the Eastern Mediterranean. Atmos Environ., 44, 43394345, doi:10.1016/j.atmosenv.2010.07.056.

Wang, X., and C. Lee, 1994: Sources and distribution of aliphatic amines in salt marsh sediment. Org. Geochem., 22, 1005-1021, doi:10.1016/0146-6380(94)90034-5.

Welsh, D. T., 2000: Ecological significance of compatible solute accumulation by micro-organisms: From single cells to global climate. FEMS Microbiol. Rev., 24, 263-290, doi:10.1111/ j.1574-6976.2000.tb00542.x.

Yamaguchi, H., J. Ishizaka, E. Siswanto, Y. Baek Son, S. Yoo, and Y. Kiyomoto, 2013: Seasonal and spring interannual variations in satellite-observed chlorophyll- $a$ in the Yellow and East China Seas: New datasets with reduced interference from high concentration of resuspended sediment. Cont. Shelf Res., 59, 1-9, doi:10.1016/j.csr.2013.03.009.

Yang, X., M. I. Scranton, and C. Lee, 1994: Seasonal variations in concentration and microbial uptake of methylamines in estuarine waters. Mar. Ecol. Prog. Ser., 108, 303-312, doi:10.3354/ meps108303.

Yao, X., and L. Zhang, 2012a: Supermicron modes of ammonium ions related to fog in rural atmosphere. Atmos. Chem. Phys., 12, 11 165-11 178, doi:10.5194/acp-12-11165-2012.
— , and — 2012b: Chemical processes in sea-salt chloride depletion observed at a Canadian rural coastal site. Atmos. Environ., 46, 189-194, doi:10.1016/j.atmosenv.2011.09.081.

_- M. Fang, and C. K. Chan, 2001: Experimental study of the sampling artifact of chloride depletion from collected sea salt aerosols. Environ. Sci. Technol., 35, 600-605, doi:10.1021/ es000964q.

A. P. Lau, M. Fang, C. K. Chan, M. Hu, and P. Aalto, 2003: Size distributions and formation of ionic species in atmospheric particulate pollutants in Beijing, China: 1Inorganic ions. Atmos. Environ., 37, 2991-3000, doi:10.1016/ S1352-2310(03)00255-3.

Yu, H., and J. Z. Yu, 2012: Polycyclic aromatic hydrocarbons in urban atmosphere of Guangzhou, China: Size distribution characteristics and size-resolved gas-particle partitioning. Atmos. Environ., 54, 194-200, doi:10.1016/j.atmosenv.2012.02.033.

Yu, J., Q. H. Hu, Z. Q. Xie, H. Kang, M. Li, Z. Li, and P. P. Ye, 2013: Concentration and size distribution of fungi aerosol over oceans along a cruise path during the Fourth Chinese Arctic Research Expedition. Atmosphere, 4, 337-348, doi:10.3390/atmos4040337.

Zhang, G., and Coauthors, 2012: Enhanced trimethylaminecontaining particles during fog events detected by single particle aerosol mass spectrometry in urban Guangzhou, China. Atmos. Environ., 55, 121-126, doi:10.1016/j.atmosenv.2012.03.038. 